\title{
Extraction of Chitosan from Crab Shell and Fungi and Its Antibacterial Activity against Urinary Tract Infection Causing Pathogens
}

\author{
S. Abirami ${ }^{1 *}$, Emilin Renitta R. ${ }^{2}$, Antony V. Samrot ${ }^{3 *}$ (D) M. Sakthikavitha ${ }^{1}$, \\ P. Revathi ${ }^{1}$, A. Mini Varsini ${ }^{1}$, Dhiva S. ${ }^{4}$, S. Saigeetha ${ }^{5}$, N. Shobana ${ }^{5}$ and P. Prakash ${ }^{5}$ \\ ${ }^{1}$ Department of Microbiology, Kamaraj College, Thoothukudi - 628 003, Tamil Nadu, India. \\ ${ }^{2}$ Department of Food Processing Technology, School of Agriculture and Biosciences, Karunya Institute of \\ Science and Technology, Karunya Nagar, Coimbatore - 641 114, India. \\ ${ }^{3}$ School of Biomedical Sciences, Faculty of Medicine, Nursing, and Bioscience, MAHSA University, Jalan SP 2, \\ Bandar Saujana Putra, 42610 Jenjarom Selangor, Malaysia. \\ ${ }^{4}$ Department of Microbiology, Sree Narayana College, Alathur, Palakkad, Kerala - 678 682, Kerala, India. \\ ${ }^{5}$ Department of Biotechnology, School of Bio and Chemical Engineering, Sathyabama Institute of Science and \\ Technology, Chennai - 600 119, Tamil Nadu, India.
}

\begin{abstract}
In this study, shells of sea crab and fungus Aspergillus niger were subjected for chitosan extraction which has been done following demineralization, deproteination and deacetylation. Chitosan yield from crab shell and fungi was $37.5 \%$ and $39.3 \%$ respectively and water binding capacity was $58.44 \%$ and $\mathbf{6 0 . 2 1 \%}$ respectively. The extracted chitosan was characterized using Fourier transform infrared spectroscopy (FTIR) and subjected for antibacterial activity against Urinary tract infection (UTI) pathogens - Klebsiella pneumoniae, Proteus mirabilis and $E$. coli. Chitosan of crab shell showed better antibacterial activity than fungal derived chitosan. Chitosan gel was prepared using the extracted chitosan where it was also showing good antibacterial activity.
\end{abstract}

Keywords: Crab shell, fungal cell, chitosan, antibacterial activity, UTI pathogens

\footnotetext{
*Correspondence: antonysamrot@gmail.com; abisasi@gmail.com

(Received: August 30, 2020; accepted: May 25, 2021)

Citation: Abirami S, Emilin RR, Antony VS, et al. Extraction of Chitosan from Crab Shell and Fungi and Its Antibacterial Activity against Urinary Tract Infection Causing Pathogens. J Pure Appl Microbiol. 2021;15(2):968-975. doi: 10.22207/JPAM.15.2.55

(C) The Author(s) 2021. Open Access. This article is distributed under the terms of the Creative Commons Attribution 4.0 International License which permits unrestricted use, sharing, distribution, and reproduction in any medium, provided you give appropriate credit to the original author(s) and the source, provide a link to the Creative Commons license, and indicate if changes were made.
} 


\section{INTRODUCTION}

Chitin, an abundant natural amino polysaccharide which is a constituent of exoskeleton of shrimp, crab etc and also seen on fungi cell walls $s^{1,2}$. Deacetylated form of chitin is chitosan which consists of polymer of $\mathrm{N}$-acetyl $\mathrm{D}$-glucosamine bonded through $\beta$-1,4glycosidic bond ${ }^{3,4}$. This chitosan has multiple functional properties and biological activities thus used in pharmaceutical, nanotechnology and agricultural industries ${ }^{5-8}$. Its antimicrobial activity made them to be used in food preservation as coating agents on wrapper of various foods 8. Its non-toxicity and non-allergenicity made them to be used in biomedical applications and also used in treating wounds ${ }^{9-12,4}$. Chitosan coated nanoparticles are used for heavy metal removal, nanocarrier synthesis, drug delivery etc $^{13-18}$. Urinary tract infections (UTI), commonly caused by bacteria and their pathogenicity depends on host biological behavioral factors and properties of the infecting uropathogens ${ }^{19}$. The major bacteria causing UTI are Proteus mirabilis, Enterococcus faecalis, Escherichia coli, Pseudomonas aeruginosa, and Klebsiella pneumoniae ${ }^{20}$. Emergence of drug resistance making the treatment harder, and development of new drugs become inevitable ${ }^{21-23}$. If derived from biological sources it might be having less side effect ${ }^{22}$, chitosan is one such which can be derived from crab shell and fungal cell wall. Thus, in this study, chitosan of crab shells and fungal cell walls was extracted and used for antibacterial activity against UTI pathogens.

\section{MATERIALS AND METHODS Collection of Crab shells}

The crab shells required for the experiments were brought from local fish processing industries in Tuticorin, Tamil Nadu, India. The crab shells were washed, cleaned, dried at $70^{\circ} \mathrm{C}$ in hot air oven, powdered using blender and stored in air tight container in room temperature.

\section{Isolation and cultivation of fungi}

Soil fungi Aspergillus niger was isolated from soil and inoculated into $100 \mathrm{~mL}$ of yeast peptone glucose (YPG) medium (2.0\% glucose, yeast peptone glucose $-0.2 \%$ yeast extract, and $1.0 \%$ peptone) and incubated at $28^{\circ} \mathrm{C}$ for 5 days.
The fungal mycelium was transferred into $500 \mathrm{~mL}$ of YPG medium. The flasks containing inoculum were kept for incubation without shaking at $28^{\circ} \mathrm{C}$ for 5 days. Mycelium was obtained through filtration process using Whatman filter paper and harvested mycelia was washed with distilled water and dried in hot air oven and ground to a powder and stored in a sterile airtight container at room temperature for extraction for chitosan. The extraction of chitosan consisted of three steps such as, deproteinization, demineralization and deacetylation.

Extraction, fat binding capacity (FBC) and water binding capacity (WBC) of chitosan

Deproteinization of both the fungi and crab shell was done as prescribed ${ }^{24}$. Demineralization and deacetylation of chitin were done following the earlier reports ${ }^{25-26}$. Determination of yield of crab shell and fungal biomass chitosan was done ${ }^{27}$. The fat binding capacity and water binding capacity of chitosan were measured using the protocol of No et al..$^{28}$.

\section{Characterization of chitosan}

FTIR characterization of sample was performed with a Perkin Elmer spectrum RX1 instrument within a frequency range of $400-4000$ $\mathrm{cm}^{-1}$. Degree of deacetylation of chitosan was determined ${ }^{29}$.

Identification of UTI organisms and determination of antibiotic susceptibility

Urine sample isolates were collected from AVM hospital, Tuticorin, Tamil Nadu, India. Sterile nutrient agar plates were prepared and inoculated with urine sample. After $24 \mathrm{~h}$ of incubation, observed colonies were identified through the morphological and biochemical characteristics. All the organisms were checked for their antibiotic resistance pattern against commercial antibiotic discs. Antibiotic susceptibility was determined using commercially available disc diffusion assay.

\section{Antibacterial activity of chitosan}

Chitosan solution was done by dissolving chitosan in $1 \%$ of acetic acid. This solution was used for testing antibacterial activity ${ }^{30}$. For antibacterial activity, Mueller Hinton agar (MHA) medium was prepared and sterilized. The culture of pathogenic microorganisms was swabbed onto the surface of sterile MHA plates. The antibacterial activity was performed by agar well diffusion method ${ }^{31}$. Chitosan solution of different concentration $(10 \mu \mathrm{g}$, 
$20 \mu \mathrm{g}, 30 \mu \mathrm{g})$ was added using a micropipette into the wells $(6 \mathrm{~mm})$ punched over the MHA plates using a sterile cork borer. These agar plates were incubated for $24 \mathrm{~h}$ at $37^{\circ} \mathrm{C}$. Zone of inhibition was observed and measured around the wells after the period of incubation.

Preparation of the chitosan gels and its antibacterial activity

In order to form the gel, method described by Samano-Valencia et al. ${ }^{32}$ was followed and antibacterial activity was performed by agar well diffusion method.

\section{RESULTS}

The yield of extracted chitosan of crab shell and fungi was found to be $38 \%$ and $39.3 \%$ respectively (Table 1 ). The moisture content of the chitosan extracted from crab and fungi was found to be $64.34 \%$ and $66 \%$ respectively. The water binding capacity and fat binding capacity of crab and fungal chitosan was found to be $58.44 \%$, $60.21 \%$ and $40 \%, 41 \%$ respectively (Table 2 ).

Table 1. Percentage of extracted crab and fungal chitosan

\begin{tabular}{llccc}
\hline S.No & Source & $\begin{array}{c}\text { Initial weight } \\
(\mathrm{g})\end{array}$ & $\begin{array}{c}\text { Final weight } \\
(\mathrm{g})\end{array}$ & $\begin{array}{c}\text { \% of extracted } \\
\text { Chitosan }\end{array}$ \\
\hline 1. & Crab shell & 20 & 7.5 & 37.5 \\
2. & Fungal biomass & 20 & 7.86 & 39.3 \\
\hline
\end{tabular}

Table 2. Physicochemical characterization of extracted chitosan

\begin{tabular}{llll}
\hline S.No & Physicochemical Characteristics & \multicolumn{2}{c}{ Values } \\
\cline { 3 - 4 } & & $\begin{array}{l}\text { Crab Shell } \\
\text { chitosan }\end{array}$ & $\begin{array}{l}\text { Fungal Biomass } \\
\text { Chitosan }\end{array}$ \\
\hline 1 & $\begin{array}{l}\text { \% Water binding capacity of } \\
\text { Extracted Chitosan }\end{array}$ & 58.44 & 60.21 \\
2 & $\begin{array}{l}\text { \% Fat binding capacity of } \\
\text { extracted Chitosan }\end{array}$ & 40 & 41 \\
3 & $\begin{array}{l}\text { Moisture content } \\
\text { Degree of deacetylation (\%) }\end{array}$ & $\begin{array}{l}64.34 \\
9\end{array}$ & 66 \\
\hline
\end{tabular}

The appearance of extracted chitosan from crab shell was yellowish white in color (Fig.1a) and from fungi it was black in color due to its conidial nature (Fig.1b). FTIR spectrum of crab chitosan recorded major peaks lying between
$500.05 \mathrm{~cm}^{-1}$ and $3880.60 \mathrm{~cm}^{-1}$ (Fig. 2). FT-IR spectrum of the fungal chitosan recorded major peaks lying between $564.67 \mathrm{~cm}^{-1}$ and $3451.92 \mathrm{~cm}^{-}$ ${ }^{1}$. In this way, our study of FT-IR analysis showed spectral peaks of extracted chitosan from crab
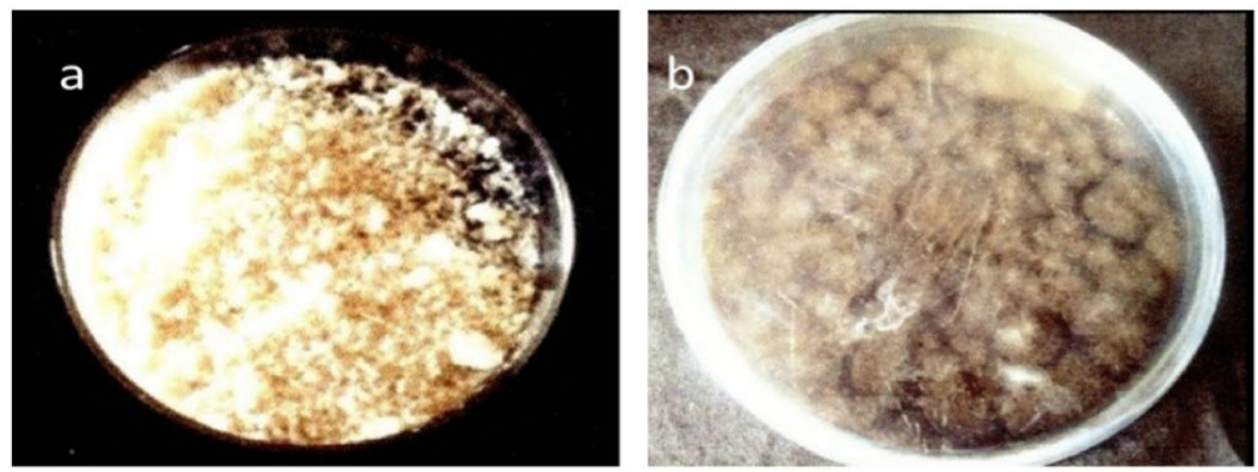

Fig. 1. Extracted chitosan a) Crab shell derived b) fungal derived 


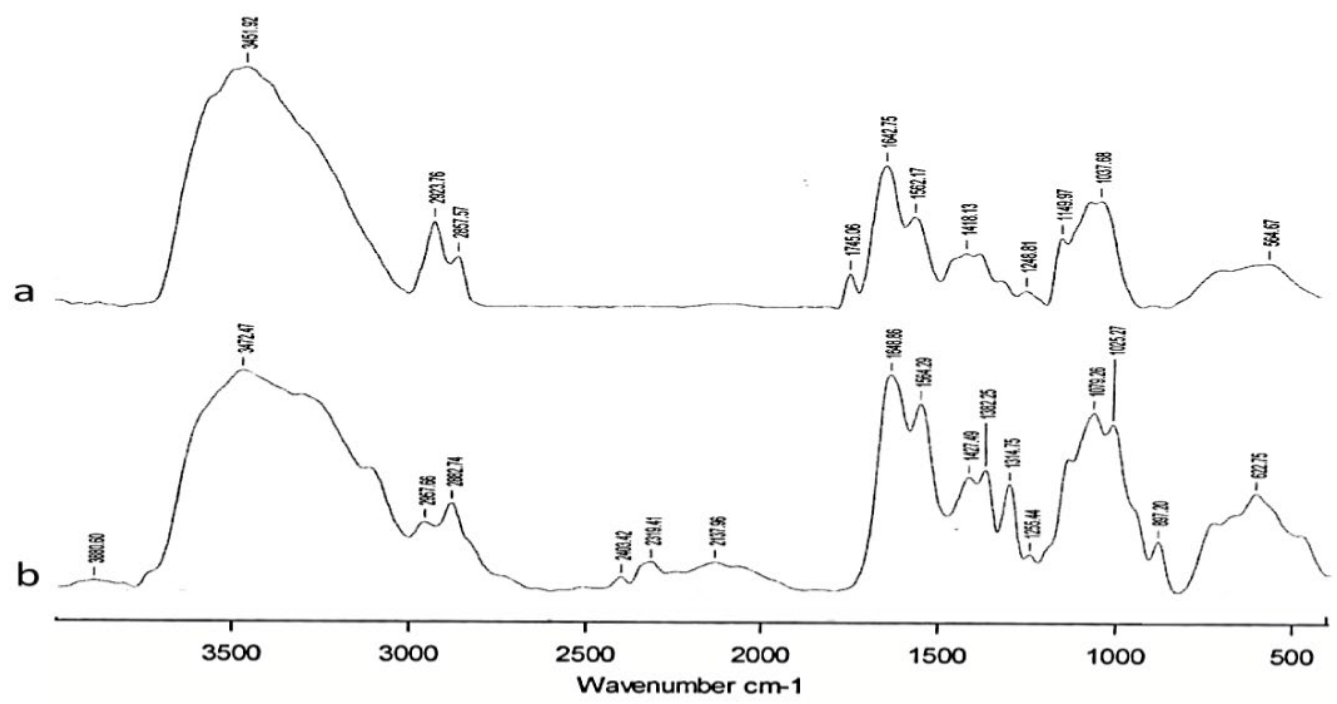

Fig. 2. Fourier transform infrared spectroscopy (FTIIR) of chitosan a) Crab shell derived b) fungal derived

and fungi were confirmed with their functional groups and crab and fungal chitosan with degree of deacetylation (DD) of $90 \%, 60 \%$ respectively.

The identified organisms of urine samples were Escherichia coli, Proteus mirabilis and Klebsiella pneumoniae through its biochemical characteristics. All the organisms were showing resistance to one or two antibiotics used in this study (Table 3). $20 \mu \mathrm{g}$ of crab shell derived chitosan showed $6 \mathrm{~mm}$ zone of inhibition against Escherichia coli whereas $30 \mu \mathrm{g}$ showed $8 \mathrm{~mm}$ against K.pneumoniae (Table 4 and Fig. 3). The highest zone of inhibition was observed at $30 \mu \mathrm{g}$ of both crab shell chitosan and fungal chitosan against all bacteria (Table 4, Fig. 3 and 4).

Table 3. Antibiotic susceptibility of UTI pathogens

\begin{tabular}{llcccc}
\hline S.No & Pathogens & $\begin{array}{c}\text { Tetracycline } \\
\text { (30mcg) }\end{array}$ & $\begin{array}{c}\text { Streptomycin } \\
(10 \mathrm{mcg})\end{array}$ & $\begin{array}{c}\text { Norfloxacin } \\
(10 \mathrm{mcg})\end{array}$ & $\begin{array}{c}\text { Methicillin } \\
\text { (10mcg) }\end{array}$ \\
\hline 1 & E. coli & $\mathrm{R}$ & $\mathrm{I}$ & $\mathrm{R}$ & $\mathrm{R}$ \\
2 & P. mirabilis & $\mathrm{I}$ & $\mathrm{I}$ & $\mathrm{R}$ & $\mathrm{R}$ \\
3 & K. pneumoniae & $\mathrm{R}$ & $\mathrm{R}$ & $\mathrm{I}$ & $\mathrm{R}$ \\
\hline
\end{tabular}

R- resistant, I - intermediate

Table 4. Antibacterial activity of crab chitosan against the urinary pathogens

\begin{tabular}{lcccccc}
\hline Organism & \multicolumn{6}{c}{ Zone of inhibition $(\mathrm{mm})$} \\
\cline { 2 - 7 } & $\begin{array}{c}\text { Crab } \\
\text { chitosan } \\
(10 \mu \mathrm{g})\end{array}$ & $\begin{array}{c}\text { Fungal } \\
\text { chitosan } \\
(10 \mu \mathrm{g})\end{array}$ & $\begin{array}{c}\text { Crab } \\
\text { chitosan } \\
(20 \mu \mathrm{g})\end{array}$ & $\begin{array}{c}\text { Fungal } \\
\text { chitosan } \\
(20 \mu \mathrm{g})\end{array}$ & $\begin{array}{c}\text { Crab } \\
\text { chitosan } \\
(30 \mu \mathrm{g})\end{array}$ & $\begin{array}{c}\text { Fungal } \\
\text { chitosan } \\
(30 \mu \mathrm{g})\end{array}$ \\
\hline $\begin{array}{l}\text { E. coli } \\
\text { P. mirabilis }\end{array}$ & - & 2 & 6 & 5 & 8 & 6 \\
K. pneumoniae & - & - & - & 2 & 5 & 2 \\
& -1 & - & 2 & 3 \\
\hline Journal of Pure and Applied Microbiology & & & & & \\
\hline
\end{tabular}



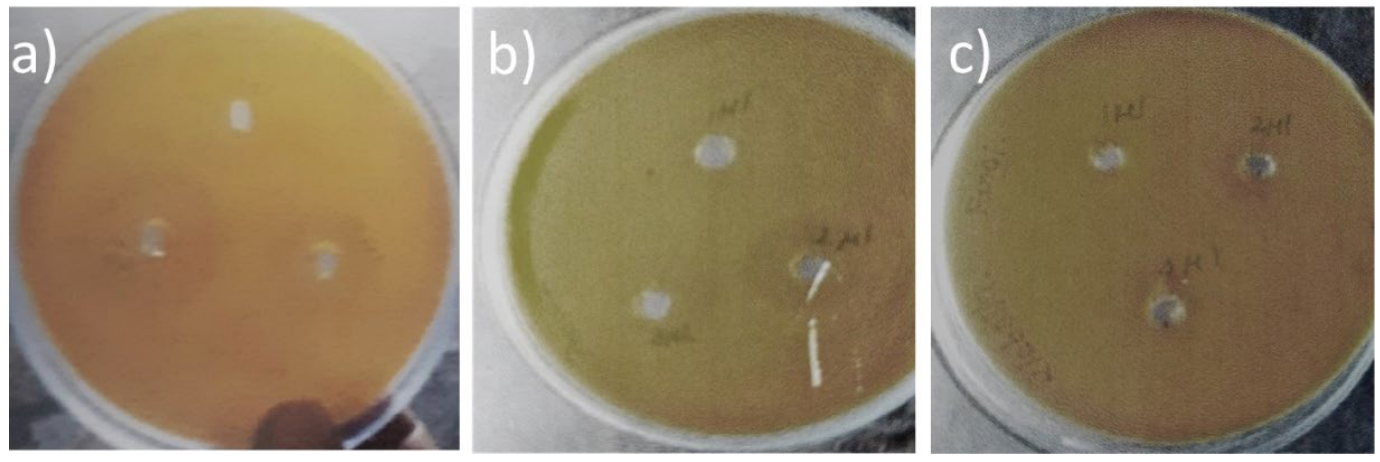

Fig. 3. Antibacterial activity of crab shell chitosan a) E.coli b) Proteus mirabilis c) K.pneumoniae
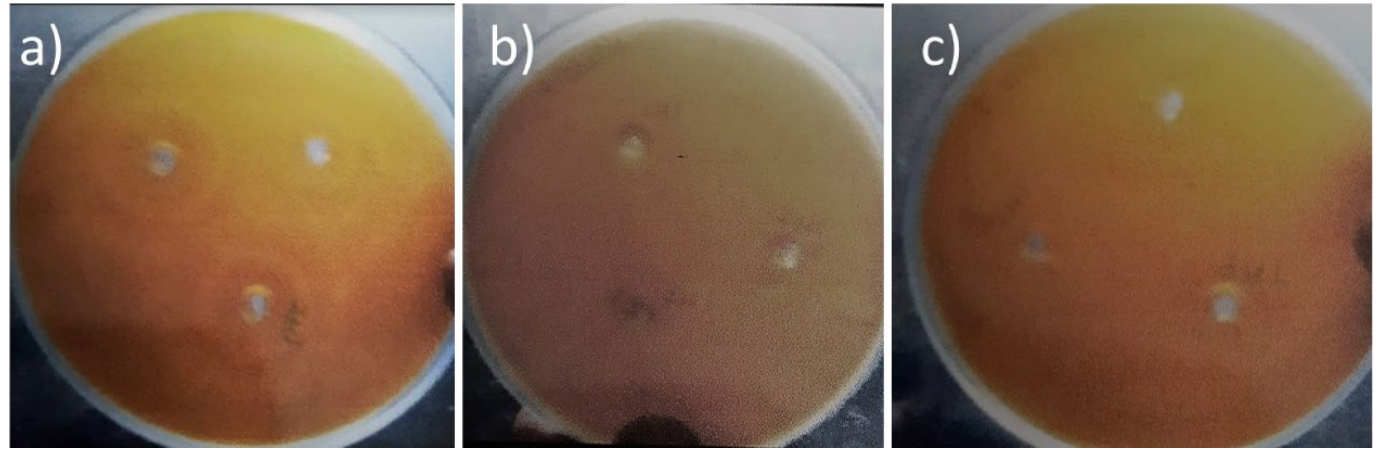

Fig. 4. Antibacterial activity of fungal chitosan a) E. coli b) Proteus mirabilis c) K. pneumoniae

Antibacterial activity of crab shell chitosan gel showed maximum zone of inhibition i.e. 6 $\mathrm{mm}$ against Escherichia coli (Fig. 5) where fungal chitosan showed maximum zone of inhibition at $100 \mu \mathrm{g}$ against Proteus mirabilis (4 mm).

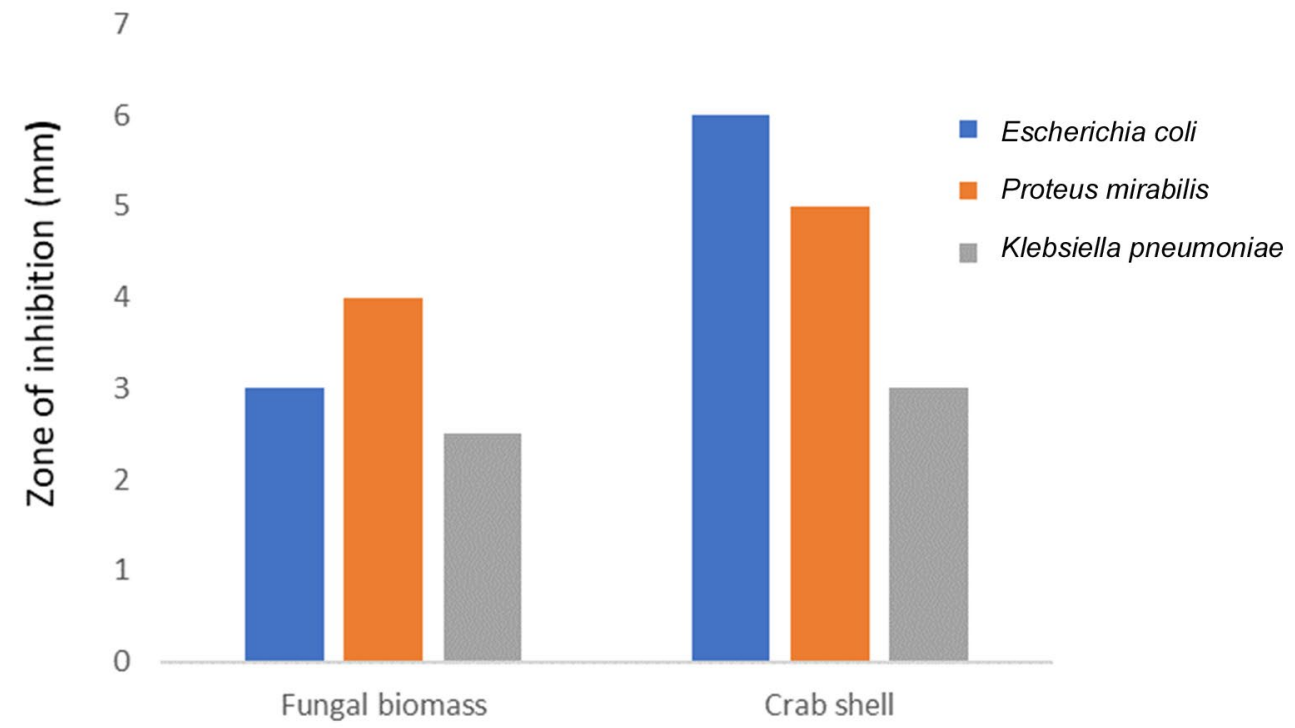

Fig. 5. Antibacterial activity of chitosan gel against UTI pathogens 


\section{DISCUSSION}

The wider applications of chitosan are because of its biodegradability, biocompatibility and low toxicity ${ }^{33}$. The maximum yield of chitin and chitosan in fungi was obtained in late logarithmic phase $^{34}$. Yield\% of chitosan from Scylla serrata was $38.23 \%{ }^{35,36}$ where in this study, it has also shown crab chitosan yield\% of $37.5 \%$. Chitosan extraction using $\mathrm{NaOH}$ helps in binding with acetyl group of chitins, forms sodium acetate aids in the extraction of chitosan ${ }^{37}$. It was found that the fat binding capacity was more with fungal derived chitosan than the crab derived chitosan. No et al. ${ }^{28}$ reported this as a physical property of chitosan to hold water or fat held and getting trapped in the structure and swells, thus can be used for drug delivery. Chemical methods for deproteination and demineralization are effective ${ }^{38}$, the colour of chitosan obtained was different which might the influence of conidia of fungal strain. Kobayashi et al. ${ }^{39}$ pointed that increased advantage of chitosan of fungi made them to receive great attention compared to chitosan extracted from crustacean shell. The major advantage of using chitosan extracted from fungi mycelium is, it is obtained easily by fermentation process and available at all seasons and geographical location but collection of crustacean waste supplies is limited by fishing industry locations and seasons ${ }^{40}$. chitin from fungal species can be derived from Phycomycetes, Basidiomycetes, and Ascomycetes ${ }^{41}$.

Peaks at $564.67 \mathrm{~cm}^{-1}$ and $3451.92 \mathrm{~cm}^{-1}$ of fungal chitosan and $500.05 \mathrm{~cm}^{-1}$ and $3880.60 \mathrm{~cm}^{-1}$ of crab shell derived chitosan where there are on par with the earlier reports of chitosan extracted from various sources ${ }^{42-44}$. The degree of deacetylation (DD) is calculated by identifying the functional group present in the extracted chitosan ${ }^{45}$. The DD of crab shell derived chitosan and fungal chitosan were $90 \%$ and $60 \%$ respectively, Thus, DD was more with crab shell chitosan than fungal, so crab shell chitosan was purer than fungal chitosan. Chitosan behaves like a polyelectrolyte by getting dissolved in the acid aqueous solution when the degree of deacetylation reaches above $50 \%{ }^{46}$. In our study, both extracted chitosan was insoluble in water and highly soluble in acidic aqueous solutions. Chitosan molecules do have a pH below 6 with a strong positive charge when the DD is high $(>85 \%)^{47}$. Chitosan extracted from crab shell showed excellent antibacterial activity compared to fungal chitosan.

Escherichia coli, Proteus mirabilis and Klebsiella pneumoniae were identified by their biochemical characteristics ${ }^{48}$. The highest zone of inhibition was observed for crab shell chitosan as well as the chitosan gel than fungal chitosan / chitosan gel against all bacteria. Kong et al. ${ }^{49}$ reported that crab shells are rich source of chitosan and this chemical constituent greatly effects antibacterial activities. And also, Klaykruayat et al. ${ }^{50}$ reported that smaller oligomeric chitosan can penetrate into the cell membrane and inhibits RNA transcription and prevents the cell growth therefore it is observed that molecular weight plays a major role in determining the antibacterial activities of chitosan. Moreover, chitosan absorbs the electronegative substrate of proteins and may disrupt the physiological activities of microbes and leads to cell death ${ }^{51}$. Lim and Hudson ${ }^{52}$ reported that the interaction between the anionic components and intracellular components are due to the leakage caused by changing the cellular permeability by the polycationic nature of chitosan and leading to cell death.

\section{CONCLUSIONS}

In this study, crab shell and fungi were used for deriving chitosan. The derived chitosan were characterized using FTIR and used for making chitosan gel. Both the chitosan and chitosan gel were found to have antibacterial activity against UTI pathogens, where crab shell derived chitosan and chitosan gel were showing more activity than the fungal chitosan.

\section{ACKNOWLEDGMENTS}

S. Abirami would like to thank the Management, Kamaraj College for their support to do this work.

\section{CONFLICT OF INTEREST}

The authors declare that there is no conflict of interest.

\section{AUTHORS' CONTRIBUTION}

All authors listed have made a substantial, direct and intellectual contribution to the work, and approved it for publication. 


\section{FUNDING}

None.

\section{DATA AVAILABILITY}

All datasets generated or analyzed during this study are included in the manuscript.

\section{ETHICS STATEMENT}

Not applicable.

\section{REFERENCES}

1. Yeul VS, Rayalu SS. Unprecedented Chitin and Chitosan: A Chemical Overview. J Polym Environ. 2013;21:606614. doi: 10.1007/s10924-012-0458-x

2. Bhuiyan MA, Hossain MD, Zakaria A, Islam MN, Uddin MZ. Chitosan Coated Cotton Fiber: Physical and Antimicrobial Properties for Apparel Use. J Polym Environ. 2017;25:334-342. doi - 10.1007/s10924-0160815-2

3. Chawla SP, Kanatt SR, Sharma AK. Chitosan. Polysaccharides bioactivity and biotechnology. Springer, Cham. 2014;219-246. doi: 10.1007/978-3319-16298-0_13

4. Shariatinia Z. Pharmaceutical applications of chitosan. Advances in Colloid and Interface Science. 2019;263:131-194. doi: 10.1016/j.cis.2018.11.008

5. Ul-Islam M, Shah N, Ha JH,Park JK. Effect of chitosan penetration on physico-chemical and mechanical properties of bacterial cellulose. Korean J Chem Eng. 2011;28:1736. doi: 10.1007/s11814-011-0042-4

6. Ruiz-Herrera J, Sentandreu R. Fungal cell wall: Structure, synthesis, and assembly. In J. RuizHerrera (Ed.). Curr Med Mycol. 1989;168-217. doi: 10.1007/978-1-4612-3624-5_8

7. Bashar MM, Khan MA. An overview on surface modification of cotton fiber for apparel use. J Polym Environ. 2013;21:181-190. doi: 10.1007/s10924-0120476-8

8. Abirami S, Nagarajan D, Samrot AV, Varsini MA, Sugasini A, Anand DA. Extraction, Characterization, and Utilization of Shrimp Waste Chitin Derived Chitosan in Antimicrobial Activity, Seed Germination, Preservative, and Microparticle Formulation. Biointerface Research in Applied Chemistry. 2021;11(2):8725-8739. doi: 10.33263/BRIAC112.87258739

9. Mi FL, Shyu SS, Wu YB, Lee ST, Shyong JY, Huang RN. Fabrication and characterization of a sponge-like asymmetric chitosan membrane as a wound dressing. Biomaterials. 2001;22:165-173. doi: 10.1016/S01429612(00)00167-8

10. Samrot AV, SenthilKumar P, Bhushan S, et al. Sodium Tri Poly Phosphate Mediated Synthesis of Curcumin Loaded Chitosan-Carboxymethyl Cellulose Microparticles for Drug Delivery. International Journal of Pharmacognosy and Phytochemical Research. 2017;9(5):694-702. doi: 10.25258/phyto.v9i5.8151

11. Kong $M$, Chen XG, Xing K, Park HJ. Antimicrobial properties of chitosanand mode of action: a state of the art review. Int J Food Microbiol. 2010;144:51-63. doi: 10.1016/j.ijfoodmicro.2010.09.012

12. Batista $A C L$, Souza Neto FE, Paiva WS. Review of fungal chitosan: past, present and perspectives in Brazil. Polimeros. 2018;28:275-283. doi: 10.1590/01041428.08316

13. Samrot AV, Shobana N, Sruthi PD, Sahithya CS. Utilization of chitosan-coated superparamagnetic iron oxide nanoparticles for chromium removal. Appl. Water Sci. 2018;8:192. doi: 10.1007/s13201-018-08414

14. AV Samrot, Akanksha, T Jahnavi, et al. Chelators influenced synthesis of chitosan-carboxymethyl cellulose microparticles for controlled drug delivery. Appl Nanosci. 2016;6:1219-1231. doi: 10.1007/ s13204-016-0536-9

15. Islam N, Ferro V.Recent advances in chitosan-based nanoparticulate pulmonary drug delivery. Nanoscale. 2016;8:14341-14358. doi: 10.1039/C6NR03256G

16. Islam N, Richard D. Inhaled micro/nanoparticulate anticancer drug formulations: an emerging targeted drug delivery strategy for lung cancers. Curr Cancer Drug Targets. 2019;19:162-178. doi: 10.2174/15680 09618666180525083451

17. Peers S, Montembault A, Ladaviere C. Chitosan hydrogels for sustained drug delivery. J Control Release. 2020;326:150-163. doi: 10.1016/j.jconrel.2020.06.012

18. Samrot AV, Sahithya CS, Selvarani AJ, Pachiyappan S, Kumar SS. Surface-Engineered Super-Paramagnetic Iron Oxide Nanoparticles For Chromium Removal. International Journal of Nano Medicine. 2019;2019:8105-8119. doi: 10.2147/IJN.S214236

19. Foxman B. Epidemiology of urinary tract infections: incidence, morbidity, and economic costs. The Am J Med. 2002;113:5-13. doi:10.1016/s00029343(02)01054-9

20. Svanborg C, Godaly G. Bacterial virulence in urinary tract infection. Infect Dis Clin N Am. 1997;11:513-529. doi:10.1016/s0891-5520(05)70371-8

21. Sharma A, Chandraker S, Patel VK, Ramteke P. Antibacterial activity of medicinal plants against pathogens causing complicated urinary tract infections. Indian J Pharm Sci. 2009;71:136-139. doi: 10.4103/0250-474X.54279

22. Pandharipande SL, Bhagat PH. Synthesis of chitin from crab shells and its utilization in preparation of nanostructured film. International Journal of Science, Engineering and Technology Research. 2016;5(5):13781383.

23. Thirumurugan $R$, Radhakrishnan $B$, Samrot $A V$, Appalaraju VVSS, Raji P. Antibiogram study of urinary isolates among inpatients and outpatients at Puducherry State, South India. International Journal Of Advanced Research In Engineering And Technology (IJARET). 2019;10(6):104-111. doi: 10.34218/IJARET.10.6.2019.013

24. Al-Sagheer FA, Al-Sughayer MA, Muslim S, Elsabee $M Z$. Extraction and characterization of chitin and chitosan from marine sources in Arabian Gulf. Carbohydrate. 2009;77(2):410-419. doi: 10.1016/j. carbpol.2009.01.032

25. Rashmi SH, Mahendra BB, Maladkar K, Kittur AA. Extraction of chitin from prawn shell and preparation 
of chitosan. Res J Chem Environ Sci. 2016;4:70-73.

26. Samrot AV, Burman U, Philip SA, Shobana N Chandrasekaran K. Synthesis of curcumin loaded polymeric nanoparticles from crab shell derived chitosan for drug delivery. Informatics in Medicine Unlocked. 2018;10:159-182. doi: 10.1016/j. imu.2017.12.010

27. Mohanasrinivasan V, Mishra M, Paliwal JS, et al. Studies on heavy metal removal efficiency and antibacterial activity of chitosan prepared from shrimp shell waste. 3 Biotech. 2014;4:167-175.doi: 10.1007/s13205-0130140-6

28. No HK, Cho YI, Kim HR, Meyers SP. Effective deacetylation of chitin under 72 conditions of 15 psi $/ 121^{\circ} \mathrm{C}$. J Agric Food Chem.2000;48:2625-2627. doi:10.1021/jf990842I

29. Vigneshwari S, Gokula V. Extraction and FTIR characterization of chitosan from Portunus pelagicus (Linnaeus, 1758) shell wastes S. Int J Adv. 2018;3(10): 91-95. doi: 10.36282/IJASRM/3.10.2018.879

30. Rujiravanit RS, Kruaykitanon AM, Jameson I, Tokura S. Preparation of cross linked chitosan silk ficbroin blend films for drug delivery system. Macromol Biosci. 2003;3:604-610.doi: 10.1002/mabi.200300027

31. Samrot AV, Selvarani JA, Durga A, et al. Handbook on Phytochemical extraction, screening and its in-vitro bioactivity assays. Publisher SARAS Publications. 2019. ISBN: 978-93-86519-60-3

32. Sámano-Valencia C, Martínez-Castañón GA, Martínez-Gutiérrez $F$, et al. Characterization and biocompatibility of chitosan gels with silver and gold nanoparticles. J Nanomater. 2014;2014:543419. doi: $10.1155 / 2014 / 543419$

33. Islam S, Bhuiyan MAR, Islam MN. Chitin and chitosan: structure, properties and applications in biomedical engineering. J Polym Environ.2017;25:854-866. doi: 10.1007/s10924-016-0865-5

34. Akila RM. Fermentative production of fungal chitosan, a versatile biopolymer (perspectives and its applications). Adv App/ Sci Res. 2014;5:157-170.

35. Kiruba A, Uthayakumar V, Munirasu S, Ramasubramanian V. Extraction, Characterization and Physico .Chemical Properties of Chitin and Chitosan from Mud Crab Shell (Scylla Serrata). Biotechnol. 2013;3:44-46. doi: 10.15373/2249555X/AUG2013/14

36. Yen M-T, Yang J-H, Mau J-L. Antioxidant properties of chitosan from crab shells. Carbohydrate Polymers. 2008;74(4):840-844. doi: 10.1016/j. carbpol.2008.05.003

37. Hargono $\mathrm{H}$, Djaeni M. Utilization of chitosan prepared from shrimp shell as fat diluent. J Coast Dev. 2003;7: 31-37.

38. Kim SK,Rajapakse N. Enzymatic production and biological activities of chitosan oligosaccharides (COS): A review. Carbohydr Polym. 2005;62:357-368. doi: 10.1016/j.carbpol.2005.08.012

39. Kobayashi M, Watanabe T, SuzukiS, SuzukiM. Effect of $\mathrm{N}$-acetyl chitogexaose against Candida albicans infection of tumorbearing mice. Microbiol Immunol.
1990;34:413-426. doi: 10.1111/j.1348-0421.1990. tb01024.x

40. Yoshihara K, Shinohara Y, Hirotsu T, Izumori. Chitosan productivity enhancement in Rhizopus oryzae YPF61A by psicose. J BioSci Bioeng. 2003;95:293-297.doi: 10.1016/S1389-1723(03)80032-4

41. MMA Elsoud, El-Kady EM. Current trends in fungal biosynthesis of chitin and chitosan. Bull Nat Res Centre. 2019;43:59. doi: 10.1186/s42269-019-0105-y

42. Shobana N, Kumar PS, Raji P, Samrot AV. Utilization of crab shell-derived chitosan in nanoparticle synthesis for Curcumin delivery. Indian Journal of Geo-Marine Sciences. 2019;48(08):1183-1188.

43. Samrot AV, Shobana N, Kumar SS, Narendrakumar G. Production, optimization and characterisation of chitosanase of bacillus sp and its applications in nanotechnology. Journal of Cluster Science. 2019;30(3):607-620. doi: 10.1007/s10876-01901520-z

44. Samrot AV, Shobana N, Burman U, Philip SA, Chandrasekaran K. Utilization of crab shell derived chitosan for production of gallic acid loaded nanocomposites for drug delivery. Journal of Pharmaceutical Sciences and Research. 2018;10(9):2169-2174

45. Duarte ML, Ferreira MC, Marvao MR, Rocha J. An optimized method to determine the degree of acetylation of chitin and chitosan by FTIR spectroscopy. Int J Boil Macromol. 2002;31:1-8. doi: 10.1016/S01418130(02)00039-9

46. El-Nesr EM, Raafat Al, Nasef S, Soliman EA, Hegazy EA. Chitin and chitosan extracted from irradiated and non-irradiated shrimp wastes (Comparative analysis study). Arab J Nuclear Sci Appl. 2013;46:53-66.

47. Sorlier P, Denuziere A, Viton C, Domard A. Relation between the degree of acetylation and the electrostatic properties of chitin and chitosan. Biomacromole. 2001;2:765-772. doi: 10.1021/bm015531

48. Garrity, George Brenner, Don J, Noel RK, James RS. Bergey's Manual of Systematic Bacteriology Volume 2: The Proteobacteria, Part B: The Gammaproteobacteria Editor-in-chief: (Eds.) 2005

49. Kong $M, C h e n X G$, Liu $C S$, et al. Preparation and antibacterial activity of chitosan microspheres in a solid dispersing system. Front Mater Sci. 2008;2:214220. doi: 10.1007/s11706-008-0036-2

50. Klaykruayat B, Siralertmukul K, Srikulkit K. Chemical modification of chitosanw ith cationic hyperbranched dendritic polyamidoamine and its antimicrobial activity on cotton fabric. Carbohydr Polym. 2010;80:197-207. doi: 10.1016/j.carbpol.2009.11.013

51. Zheng LY, Zhu JF. Study on antimicrobial activity of chitosan with different molecular weights. Carbohydr Polym. 2003;54:527-530. doi: 10.1016/j. carbpol.2003.07.009.

52. Lim SH, Hudson SM. Synthesis and antimicrobial activity of a water-soluble chitosan derivative with a fiber-reactive group. Carbohydr Res. 2004; 339(2):313319. doi: 10.1016/j.carres.2003.10.024 